\title{
Activation of the c-Src tyrosine kinase is required for the induction of mammary tumors in transgenic mice
}

\author{
Chantale T. Guy, ${ }^{1,5}$ Senthil K. Muthuswamy, ${ }^{1,5}$ Robert D. Cardiff, ${ }^{2}$ Philippe Soriano, ${ }^{3}$ \\ and William J. Muller ${ }^{1,4}$ \\ ${ }^{1}$ Institute for Molecular Biology and Biotechnology, McMaster University, Hamilton, Ontario, Canada, L8S 4K1; \\ ${ }^{2}$ Department of Pathology, School of Medicine, University of California at Davis, Davis, California, 95616 USA; ${ }^{3}$ Fred \\ Hutchinson Cancer Center, Seattle, Washington 98104 USA
}

Transgenic mice expressing the polyomavirus $(\mathrm{PyV})$ middle $\mathrm{T}$ oncogene in the mammary epithelium develop multifocal mammary tumors that metastasize with high frequency. The potent transforming activity of PyV middle $T$ antigen can, in part, be attributed to its ability to associate with and to activate a number of c-Src family tyrosine kinases (c-Src, c-Yes, and Fyn). As a first step toward assessing the role of individual c-Src family tyrosine kinases in $\mathrm{PyV}$ middle $\mathrm{T}$ antigen-induced mammary tumorigenesis, we have crossed transgenic mice carrying the mouse mammary tumor virus (MMTV)/PyV middle $\mathrm{T}$ antigen fusion gene with mice bearing a disrupted c-src proto-oncogene. In contrast to the rapid tumor progression seen in the original $M M T V / P y V$ middle $T$ antigen strains, mice expressing the transgene in the absence of functional c-Src rarely developed mammary tumors. After long latency, these mice did eventually develop abnormal hyperplastic mammary tissue. This growth disturbance was correlated with elevated expression of the PyV middle $T$ antigen and the activation of the PyV middle $\mathrm{T}$ antigen-associated $\mathrm{c}-$ Yes tyrosine kinase. However, transgenic mice expressing the PyV middle $\mathrm{T}$ antigen in the mammary epithelium of wild-type or Yes-deficient mice developed multifocal mammary tumors with comparable kinetics. Taken together, these findings suggest that c-Src tyrosine kinase activity is required for PyV middle $\mathrm{T}$ antigen-induced mammary tumorigenesis and also illustrate an in vivo genetic approach to the dissection of mitogenic signal transduction pathways.

[Key Words: PyV middle T antigen; c-Src; transgenic mice; mammary tumorigenesis; metastasis; signal transduction]

Received August 12, 1993; revised version accepted November 18, 1993.

The molecular basis of the events responsible for conversion of a normal cell to a tumor cell remains a major challenge in understanding oncogenesis. For example, deregulated expression of a number of oncogenes, including neu and c-myc have been implicated in human breast cancer (Escot et al. 1986; Slamon et al. 1987). Interestingly, many of these oncoproteins appear to affect different mediators of mitogenic signal transduction pathways, including growth factors [neu differentiation factor (NDF)] (Peles et al. 1992; Wen et al. 1992), their receptors (Neu) (King et al. 1985; Yokota et al. 1986; Slamon et al. 1987,1989), and transcription factors (cMyc) (Escot et al. 1986). Growth factor-induced mitogenesis often involves the activation of tyrosine kinases, which in turn triggers a cascade of tyrosine phosphorylation events. Aberrant activation of members of the tyrosine kinase oncogene family in the mammary epithelium of transgenic mice can have deleterious conse-

\footnotetext{
${ }^{4}$ Corresponding author.

${ }^{5}$ These authors contributed equally to this manuscript.
}

quences. For example, constitutive activation of the Neu tyrosine kinase (Muller et al. 1988) or polyomavirus $(\mathrm{PyV})$ middle $\mathrm{T}$ antigen-associated tyrosine kinases such as c-Src and c-Yes (Guy et al. 1992a) leads to the rapid induction of multifocal mammary adenocarcinomas involving the entire mammary gland in every transgene carrier examined. In addition to the high penetrance and rapid development of mammary tumors, expression of the PyV middle $\mathrm{T}$ antigen leads to a high incidence of metastatic disease (Guy et al. 1992a).

The potent transforming properties of the PyV middle $T$ antigen result from its capacity to associate with and activate a number of cellular enzymes. In particular, PyV middle $\mathrm{T}$ antigen can activate $\mathrm{c}$-Src and $\mathrm{c}$-Yes tyrosine kinases by forming physical complexes with these proteins, thus rendering them constitutively active (Courtneidge and Smith 1983; Kombluth et al. 1987). In addition to its ability to associate with and activate different members of the Src family, the middle T oncogene is also known to interact with the $85-\mathrm{kD}$ subunit of the phosphatidylinositol-3' kinase (Whitman et al. 1985; Court- 
neidge and Hebner 1987), and this association is required for PyV middle $\mathrm{T}$ antigen-mediated tumorigenesis (Talmage et al. 1989|. Although stable complexes between protein phosphatase $2 \mathrm{~A}$ (regulatory) and $\mathrm{C}$ (catalytic) and PyV middle $\mathrm{T}$ antigen have also been detected (Pallas et al. 1990; Walter et al. 1990), their role in PyV middle T antigen-mediated tumorigenesis is not known.

Although it is clear that the interaction of PyV middle $T$ antigen with these cellular proteins plays an important role in tumorigenesis, the relative contribution of each of these protein complexes to transformation remains to be defined. To directly assess the role of c-Src in PyV middle $\mathrm{T}$ antigen-induced mammary tumorigenesis, we have crossed transgenic mice carrying the mouse mammary tumor virus (MMTV)/PyV middle T oncogene with mice carrying either disrupted c-src or c-yes genes (Soriano et al. 1991; P. Soriano, unpubl.). In contrast to the rapid induction of mammary tumors observed in parental $M M T V / P y V$ middle $\mathrm{T}$ antigen transgenic strains, mammary gland-specific expression of the PyV middle $\mathrm{T}$ antigen in mice defective in c-Src function led to the development of cystic hyperplasia of the mammary gland, which rarely progressed to full malignancy. Significantly, transgenic mice expressing PyV middle $\mathrm{T}$ antigen in the mammary epithelium of the c-Yes-deficient or wild-type mice develop multifocal metastatic mammary tumors at rates comparable to the parental MMTV/PyV middle $\mathrm{T}$ antigen strains. These observations indicate that a functional c-Src is required for PyV middle $\mathrm{T}$ antigen-induced mammary tumorigenesis and that the mammary epithelium is particularly sensitive to activation of the c-Src signal transduction pathway.

\section{Results}

Expression of the PyV middle T oncogene in the mammary epithelium results in activation of $c$-Src and c-Yes tyrosine kinases

Because PyV middle $\mathrm{T}$ antigen can associate with and activate a number of c-Src family members in established cell lines, we assessed which of these tyrosine kinases were activated in PyV middle $\mathrm{T}$ antigen-induced mammary tumors. To this end, tumor tissue extracts from several MMTV/PyV middle $\mathrm{T}$ antigen transgenic strains (MT\#121, MT\#634, MT\#668) were immunoprecipitated with either c-Src- or c-Yes-specific monoclonal antibodies and subjected to in vitro kinase assays using acid-denatured enolase as a substrate (Fig. 1A). These experiments were conducted under conditions where incorporation of ${ }^{32} \mathrm{P}$ isotope into the enolase substrate occurs in a linear fashion (Kypta et al. 1990). A prominent phosphorylated band corresponding to enolase was observed in lanes where the protein extracts were incubated with c-Src- and c-Yes-specific antibodies (lanes marked +1 . On longer exposure of the autoradiographs, a band corresponding to autophosphorylated c-Src and c-Yes was also observed in tumor extracts. Incubation of these protein extracts with a nonspecific control antibody (rabbit immunoglobulin G) (lanes marked -) re-
A
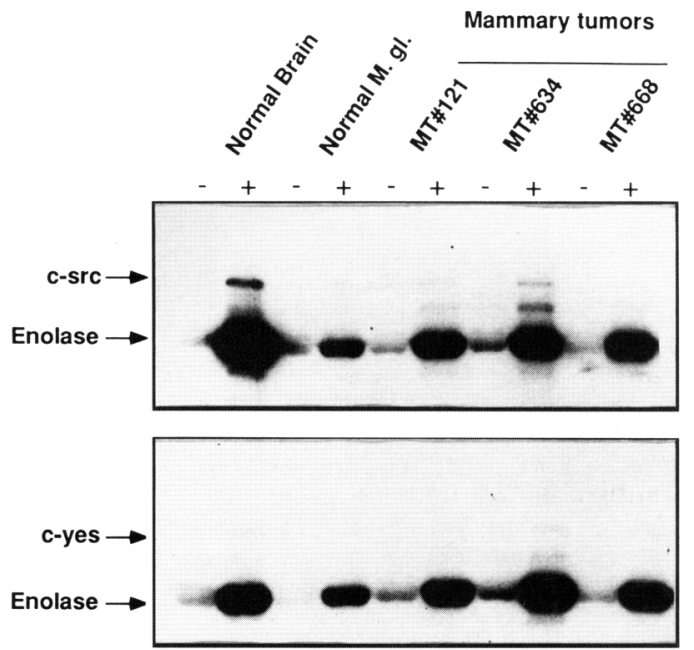

B

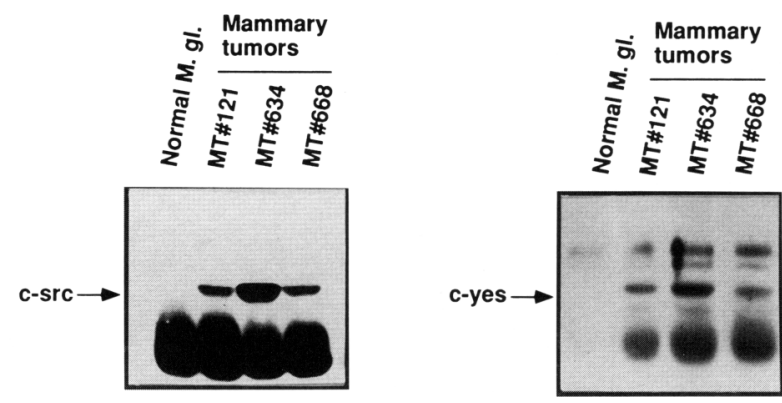

Figure 1. Activation of the c-Src family tyrosine kinases in PyV middle $T$ antigen-induced mammary tumors. $(A)$ In vitro kinase activities of mammary tumor extracts derived from the different $\mathrm{MMTV} / \mathrm{PyV}$ middle $\mathrm{T}$ antigen transgenic strains, including MT\#121 (MT\#742, 83 days of age), MT\#634 (MT\#616, 112 days of age), and MT\#668 (MT\#9313, 110 days of age). All tumors were isolated from multiparous female carriers. Each protein extract was immunoprecipitated with antibodies specific to c-Src and c-Yes (lanes marked + ). Normal rabbit serum was used as a nonspecific control antibody (lanes marked - 1 . In addition, these analyses were conducted on positive control brain (Normal brain) and nontransgenic mammary tissues (Normal M.gl.). The positions of c-Src and c-Yes kinases and exogenous enolase substrate are indicated by arrows. $(B)$ Immunoprecipitation of identical tumor and control tissue protein extracts with antisera directed against PyV middle $\mathrm{T}$ antigen followed by immunoblot analyses with c-Src- or c-Yes-specific antibodies. Also included are negative control protein extracts derived from nontransgenic mammary glands (M.gl.). The broad lower band is attributable to a cross-reactive immunoglobulin band present in the immunoprecipitates.

sulted in the weakly phosphorylated enolase band. These phosphorylated bands comigrated with those observed in brain tissue, which is known to express high levels of endogenous c-Src and c-Yes (Aguzzi et al. 1990; Soriano et al. 1991). Quantitation by PhosphorImager analysis revealed that the tumor samples from the MMTV/PyV middle $\mathrm{T}$ antigen animals had, on average, fivefold 
greater c-Src kinase and c-Yes kinase activities than the nontransgenic mammary epithelium. Although the increases in c-Src and c-Yes activities were modest, these values were observed consistently with multiple independent tumor extracts $(n=9)$. In contrast to c-Src and c-Yes, incubation of tumor and normal mammary gland extracts with a Fyn-specific antibody failed to show evidence of enhanced Fyn kinase activity in mammary tumors (data not shown).

To determine whether the activation of $\mathrm{c}$-Src and c-Yes was the result of its association with the PyV middle $\mathrm{T}$ antigen product, tumor extracts were immunoprecipitated with a PyV middle $\mathrm{T}$ antigen-specific antisera. After gel electrophoresis, these immunoprecipitates were subjected to immunoblot analyses with antisera directed against either c-Src or c-Yes. The results of these analyses revealed the presence of both c-Src and c-Yes in PyV middle $\mathrm{T}$ antigen immunoprecipitates (Fig. 1B). In addition to c-Src and c-Yes, a lower broad band corresponding to mouse immunoglobulin was also observed. As expected, application of this methodology to protein extracts derived from normal nontransgenic mammary epithelium failed to demonstrate the presence of either $\mathrm{c}$-Yes or c-Src because of the absence of the middle $\mathrm{T}$ antigen. Together, these results indicate that $\mathrm{PyV}$ middle $T$ antigen-induced mammary tumors possess elevated c-Src and c-Yes kinase activities, and this is attributable to its association with $\mathrm{PyV}$ middle $\mathrm{T}$ antigen.

\section{A functional c-Src is required for the rapid induction of metastatic mammary tumors}

Although PyV middle $\mathrm{T}$ antigen-induced mammary tumors possess elevated $\mathrm{c}$-Src and $\mathrm{c}$-Yes tyrosine kinase activities, it is unclear to what extent activation of each of these individual tyrosine kinases contributes to the overall transformed phenotype. To determine whether $\mathrm{c}-\mathrm{Src}$ is required for $\mathrm{PyV}$ middle $\mathrm{T}$ antigen-mediated mammary tumorigenesis, mice carrying a disrupted c-src gene (Soriano et al. 1991) were interbred with MMTV/ PyV middle $\mathrm{T}$ antigen transgenic mice (MT\#634, Fig. 1; Guy et al. 1992a). Using this approach, a variety of different genotypes of MMTV/PyV middle $\mathrm{T}$ antigen mice were generated, including heterozygous transgene carriers in wild-type c-src $[\mathrm{MT} /+, \mathrm{c}-s r c \mid+/+1]$, heterozygous $\mathrm{c}-\operatorname{src}[\mathrm{MT} /+, \mathrm{c}-\mathrm{src} /+1-1]$, and null c-src backgrounds $[\mathrm{MT} /+, \mathrm{c}-\mathrm{src}-1-1]$. The genotypes of each of these progeny were confirmed by Southern blot hybridization with appropriate transgene and c-src-specific probes (see Materials and methods). Consistent with previous observations (Guy et al. 1992a), all female transgenic progeny possessing at least one functional c-src allele developed multifocal mammary tumors that eventually enveloped the entire mammary epithelium by 120 days (Fig. 2A). The onset of mammary tumor formation in transgenic mice either carrying both wild-type c-src alleles $(n=30)$ or heterozygous for the c-src mutation $(n=33)$ was not significantly different (Table 1). In contrast, none of the MMTV/PyV middle T antigen transgenic mice homozygous for the c-src mutation $(n=24)$ developed mammary tumors within this time frame (Table 1).

To exclude the possibility that the lack of tumor development in these mice was attributable to alteration of transgene expression, $10 \mu \mathrm{g}$ of total RNA from the mammary glands of multiparous mice was subjected to RNase protection analyses with a probe directed to the $5^{\prime}$ segment of the PyV middle $T$ antigen cDNA. As shown in Figure $2 \mathrm{~B}$, the transgene-specific probe yields a 203 -
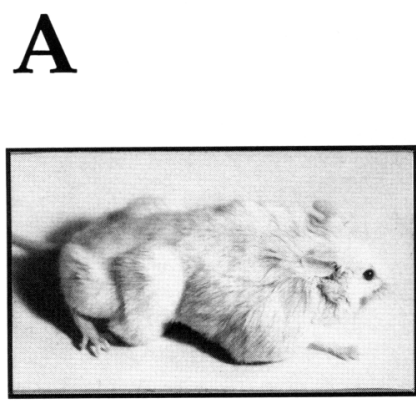

MT (+/-); c- src(+/+)

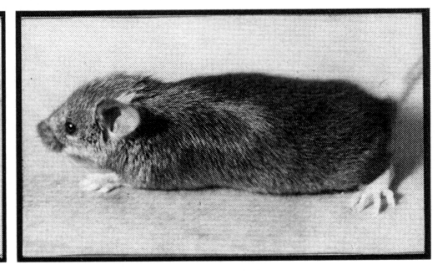

MT (+/-); c- src (-/-)
B

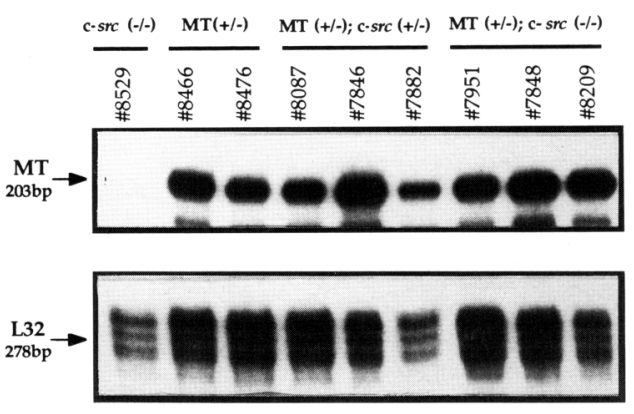

Figure 2. $\mathrm{c}-\mathrm{Src}$ is required for the induction of mammary tumors in MMTV/PyV middle $\mathrm{T}$ antigen transgenic mice. $|A|$ Transgenic mice carrying the PyV middle T oncogene in a wild-type c-src (left, \#8314 70 days of age) or null c-src (\#7832, 140 days of age) genetic backgrounds. Note the extensive mammary tumors in all mammary glands of the MT\#8314 mouse and the lack of palpable tumors in the MT\#7832 mouse. $(B)$ RNase protection analyses using $10 \mu \mathrm{g}$ of total mammary tissue RNA isolated from multiparous females carrying the middle $T$ antigen transgene in wild-type, heterozygous, and homozygous $\mathrm{c}$-src backgrounds. Mammary tissue extract from a c-srCl-/ - nontransgenic animal was included as a negative control. The antisense probe used in this RNase protection analyses protects a 203-nucleotide fragment corresponding to the $5^{\prime}$ end of the PyV middle $\mathrm{T}$ antigen cDNA. To ensure that equal amounts of RNA were loaded on the gels, a L32-4 antisense probe directed against the mouse ribosomal protein L32-4A was also included in the hybridization reaction. The $\mathrm{L} 32$ probe protects a 278 -nucleotide fragment as indicated by the arrow. 
Table 1. Onset of tumors in MMTV/PyV middle T mice in $c$-src and c-yes-deficient backgrounds

\begin{tabular}{|c|c|c|c|}
\hline Genotypes & $\begin{array}{l}\text { Number } \\
\text { of animals }\end{array}$ & $\begin{array}{l}\text { Percentage } \\
\text { of animals } \\
\text { with tumors }\end{array}$ & $\begin{array}{l}T_{50} \text { for tumor } \\
\text { formation } \\
\text { (days) }\end{array}$ \\
\hline $\begin{array}{l}\mathrm{MT}+1- \\
\mathrm{c}-s r c+1+\end{array}$ & 33 & 100 & 82 \\
\hline $\mathrm{MT}+1-$ & & & \\
\hline $\begin{array}{c}\mathrm{c}-\mathrm{src}+1- \\
\mathrm{MT}+1-\end{array}$ & 30 & 100 & 86 \\
\hline $\begin{array}{c}\mathrm{c}-s r c-/- \\
\mathrm{MT}+/-\end{array}$ & 24 & 8 & $>200$ \\
\hline $\begin{array}{l}\text { c-yes }+1+ \\
\mathrm{MT}+1-\end{array}$ & 30 & 100 & 58 \\
\hline $\begin{array}{l}\text { c-yes +/- } \\
\mathrm{MT}+1-\end{array}$ & 26 & 100 & 58 \\
\hline c-yes - I- & 31 & 100 & 80 \\
\hline
\end{tabular}

The number of animals tested for each genotype and the percentage of females that developed mammary tumors, after 3 months of age, are indicated. $T_{50}$ value was calculated for each genotype and, it corresponds to the time at which at least $50 \%$ of animals developed a palpable mammary tumor.

nucleotide protected fragment. To ensure that equal quantities of RNA were loaded, an rpL32 antisense probe directed against the mouse ribosomal protein L32-4A was also included in the hybridization reaction. The results showed that the mammary glands of mice from different c-src genotypes expressed equivalent levels of transgene RNA (Fig. 2B). Consistent with the results of these RNase protection analyses, immunoblot analyses with PyV middle $\mathrm{T}$ antigen-specific antisera revealed equivalent levels of PyV middle $\mathrm{T}$ antigen protein within the mammary epithelium of these mice (data not shown). Therefore, the inability of PyV middle T antigen mice to develop tumors in a c-src null genetic background was not attributable to differences in transgene expression.

The histological appearance of the mammary tissue derived from MMTV/PyV middle $\mathrm{T}$ antigen transgenic mice possessing at least one functional c-src allele exhibited dramatic differences in comparison to mammary tissue from transgenic mice homozygous for the disrupted c-src gene (Fig. 3). In contrast to wild-type FVB mammary glands (Fig. 3A), whole-mount examination of virgin mammary tissue from female MMTV/PyV middle $\mathrm{T}$ antigen mice heterozygous for the c-src mutation revealed the presence of multiple mammary adenocarcinomas as early as 60 days of age (Fig. $3 \mathrm{C}$ ). These analyses failed to detect comparable histological lesions in older virgin transgene carriers ( 100 days of age) lacking c-Src function (data not shown). In older multiparous or virgin female transgenic mice homozygous for the disrupted c-src gene, mammary epithelial hyperplasias have been detected (Fig. 3E). Although these mammary epithelial hyperplasias can eventually envelope the entire mammary fat pad, they rarely progress to full malignancy. Of the female transgenic mice lacking $\mathrm{c}$-Src function that have lived to an age of 3 months or older $(n=24)$, only two animals have developed focal mammary adenocarcinomas, and this occurred only after long latency 7 months of age; Table 1). Consistent with these findings, the mammary epithelial hyperplasias observed in the c-src-deficient background were histologically distinct from the middle $\mathrm{T}$ antigen-induced mammary tumors. In contrast to the proliferative multilayered epithelium observed in PyV middle $\mathrm{T}$ antigen-induced mammary tumors, the hyperplasias observed in the c-src null background were comprised of complex ducts lined by a single epithelial layer (Fig. 3D,F).

\section{Detection of PyV middle T antigen-associated tyrosine kinase activity in the mammary tissue of c-Src-deficient mice}

The epithelial hyperplasias observed in c-Src-deficient mice expressing the PyV middle $\mathrm{T}$ oncogene could con-

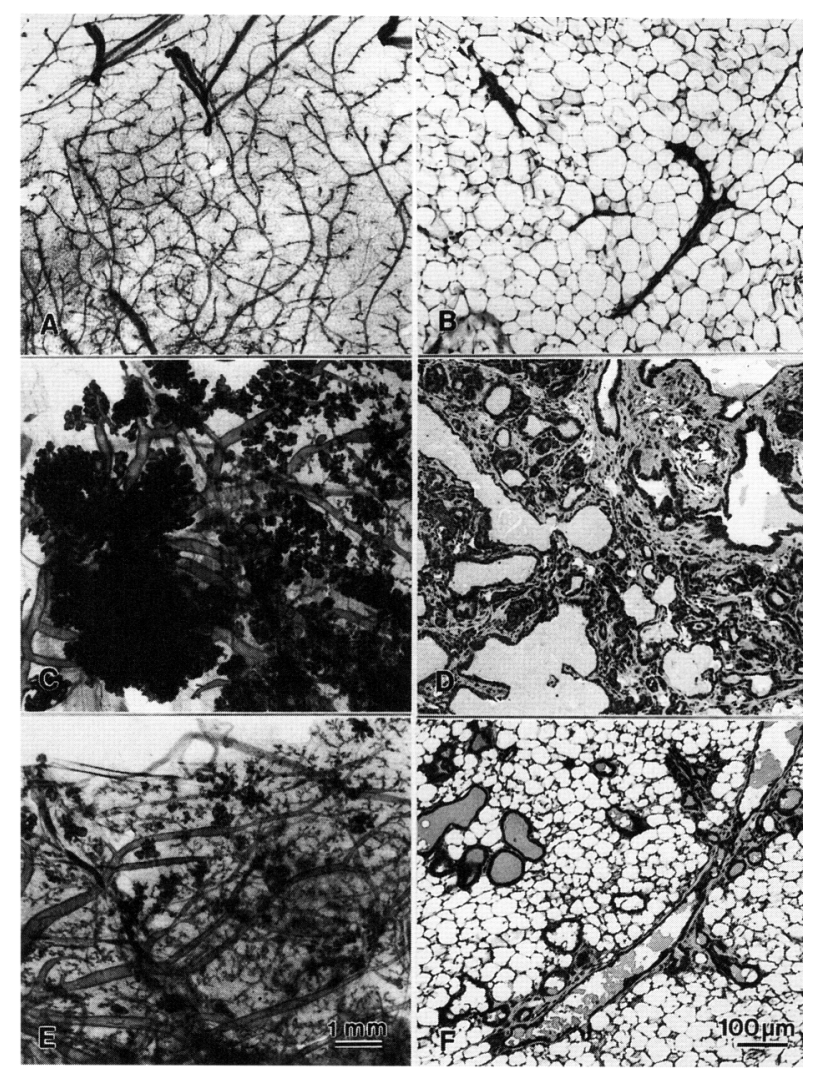

Figure 3. Histopathology of the MMTV/PyV middle $\mathrm{T}$ antigen mice carrying possessing disrupted c-src alleles. A panel of photomicrographs shows the appearance of hematoxylin-stained whole-mount (left: $A, C, E$, at $4.9 \times$ ) and hematoxylin and eosinstained microscopic section (right: $B, D, F$ at $48.6 \times$ ) of virgin female FVB $|A, B|, \mathrm{MT}(+1-$ ); $\mathrm{c}-\mathrm{src} \mid+1-)$ (MT\#7698 at 75 days of age) $(C, D)$ and $\mathrm{MT}(+1-1 ; \mathrm{c}-\mathrm{src}(-1-1$ transgenic animal (MT\#7832 at 140 days of age) $\langle E, F\rangle$. Note the slender, nonbranching ducts of the wild-type animal, the proliferative multilayered structures in the MT\#7698 animal, and the dilated complex ducts lined by a single epithelial layer in the MT\#7832 animal. 
ceivably result from activation of the PyV middle $\mathrm{T}$ antigen-associated c-Yes tyrosine kinase. To test this possibility, in vitro kinase assays were conducted on the mammary tissue derived from MMTV/PyV middle T antigen transgenic mice carrying either wild-type or mutant c-src alleles with antisera directed against PyV middle $\mathrm{T}$ antigen, c-Src, and c-Yes (Fig. 4). Incubation of these tissue extracts with antisera against the PyV middle $\mathrm{T}$ oncogene and exogenous enolase substrate indicated that PyV middle $\mathrm{T}$ antigen-associated activity could be detected in mice heterozygous or homozygous for the c-src mutation (Fig. 4A). As expected, incubation

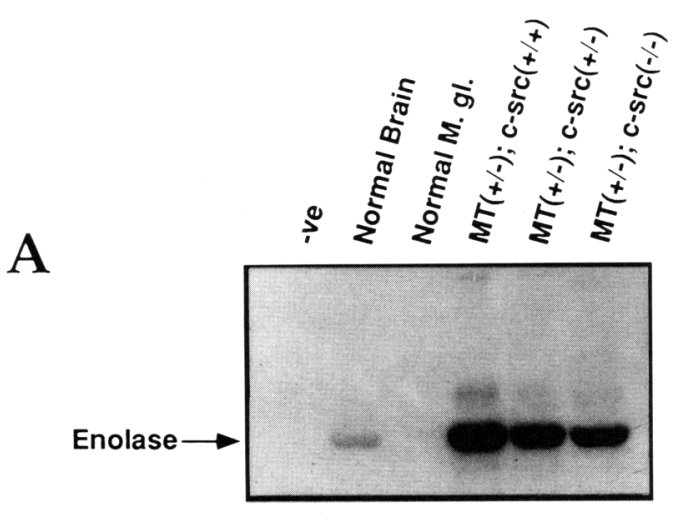

B
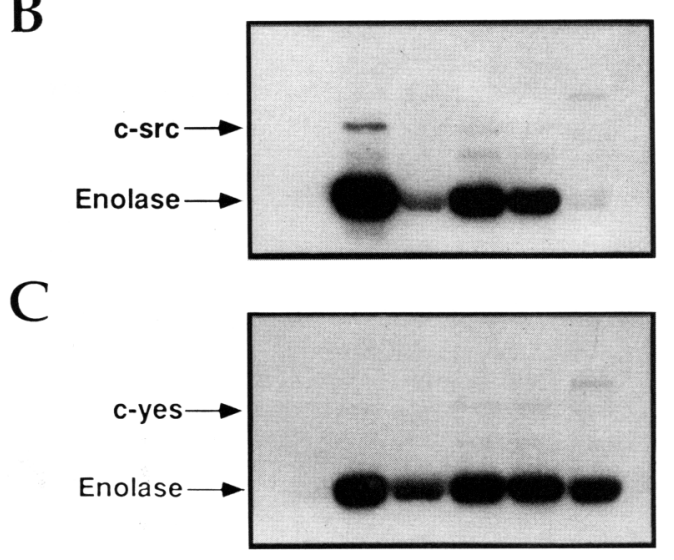

Figure 4. Detection of PyV middle $\mathrm{T}$ antigen-associated c-Yes kinase activity in mammary tissues defective in c-Src function. Shown are in vitro kinase activities of PyV middle T antigen $(A)$, c-Src $(B)$, and c-Yes $(C)$ derived from mammary tissue extracts from multiparous female MT $(+/-) ; \mathrm{c}-\mathrm{src} \mid+/+)(\mathrm{MT} \# 1907$ at 90 days of age), MT $(+/-) ; \mathrm{c}-$ src| $+/-\mid$ (MT\#7849 at 150 days of age), and MT( $+1-$ ); c-src( $-1-$ ) (MT\#9184 at 125 days of age). Protein extracts were incubated with Glu-Glu raised against PyV middle $\mathrm{T}$ antigen, a monoclonal antibody that recognizes c-Src (mAb 327, Oncogene Sci.) or a monoclonal antibody specific for c-Yes (3H9) (Sukegawa et al. 1990). In addition, these analyses were conducted on brain tissue (Normal brain) that served as a positive control for c-Src and c-Yes activity. Nontransgenic mammary tissue was also included (Normal M. gl) as a negative control tissue. A negative control antibody used in these analyses is brain tissue incubated with normal rabbit sera (lane labeled - ve). The positions of c-Src, c-Yes, and the exogenous enolase substrate are illustrated by arrows. of tissue extracts derived from either nontransgenic brain or nontransgenic mammary gland with PyV middle $T$ antigen-specific antisera failed to exhibit significant PyV middle T antigen-associated kinase activity. Quantitative analyses of middle $\mathrm{T}$ antigen-associated kinase activity (Fig. 4A) revealed that the tissue extracts derived from transgenic mice either heterozygous or homozygous for the disrupted c-src allele possessed $60 \%$ and $40 \%$ of the levels observed in the mammary glands of transgenic mice possessing both wild-type c-src alleles. To assess whether phosphorylation of PyV middle $\mathrm{T}$ antigen protein in the c-src null genetic background was attributable to the activation of the c-Yes tyrosine kinase, in vitro kinase assays were also conducted with antisera directed against c-Yes and c-Src. As expected, in vitro kinase analyses with c-Src-specific antibodies showed no evidence of c-Src kinase activity in mammary tissues obtained from transgenic mice lacking c-Src function (Fig. 4B). However, comparable levels of c-Yes kinase activity could be detected in tissues from transgenic mice carrying either wild-type or disrupted c-src genes (Fig. 4C).

The elevated PyV middle antigen T-associated kinase activity observed in the c-src null background is likely attributable to its association with the c-Yes kinase, as immunoprecipitation with antibodies against PyV middle $T$ antigen followed by immunoblot analyses with c-Yes-specific antibodies revealed the presence of c-Yes in middle $\mathrm{T}$ antigen immunoprecipitations (data not shown). These observations suggest that the mammary epithelial hyperplasias observed in MMTV/PyV middle $\mathrm{T}$ antigen transgenic mice lacking a functional $\mathrm{c}-\mathrm{Src}$ is likely attributable to the activation of $\mathrm{c}$-Yes tyrosine kinase by PyV middle $\mathrm{T}$ antigen.

\section{c-Yes is dispensable for PyV middle T antigen- mediated mammary tumorigenesis}

One possible interpretation of the cross between the MMTV/PyV middle T antigen and c-Src-deficient strains is that transformation of the mammary epithelial cell by the middle $\mathrm{T}$ oncogene requires the activity of both the middle $\mathrm{T}$ antigen/c-Src and middle $\mathrm{T}$ antigen/c-Yes complexes to transform the mammary epithelial cell. To explore this possibility further, MMTV/middle T antigen strains were crossed with c-Yes-deficient mice. Unlike c-Src-deficient mice, which suffer from osteopetrosis (Soriano et al. 1991), c-Yes-deficient mice display no obvious abnormalities and will be described elsewhere (P. Soriano, unpubl.). As shown in Table 1, the onset of mammary tumor formation in mice carrying one or both wild-type c-Yes alleles did not differ significantly. Interestingly, all female transgenic mice expressing the middle $\mathrm{T}$ antigen transgene in the c-Yes-deficient background developed multifocal mammary tumors (Table 1). The mammary tumors that arose in c-Yes-deficient mice were histologically indistinguishable from tumors observed in the original MMTV/PyV middle $\mathrm{T}$ antigen strains (data not shown).

To test whether the tumors arising in the c-Yes-defi- 
cient strains resulted from the activation of $\mathrm{PyV}$ middle $\mathrm{T}$ antigen-associated $\mathrm{c}$-Src kinase activity, in vitro kinase assays were conducted on mammary tissue derived from various genotypes with antisera specific for PyV middle $\mathrm{T}$ antigen, $\mathrm{c}$-Src, and c-Yes (Fig. 5). Mammary tumors derived from transgenic mice heterozygous or homozygous for the disrupted c-yes alleles possessed $68 \%$ or $33 \%$, respectively, of the middle $\mathrm{T}$ antigen-associated kinase activity observed in the wild-type c-Yes background (Fig. 5A). In vitro kinase analyses with c-Srcand c-Yes-specific antisera revealed comparable levels of

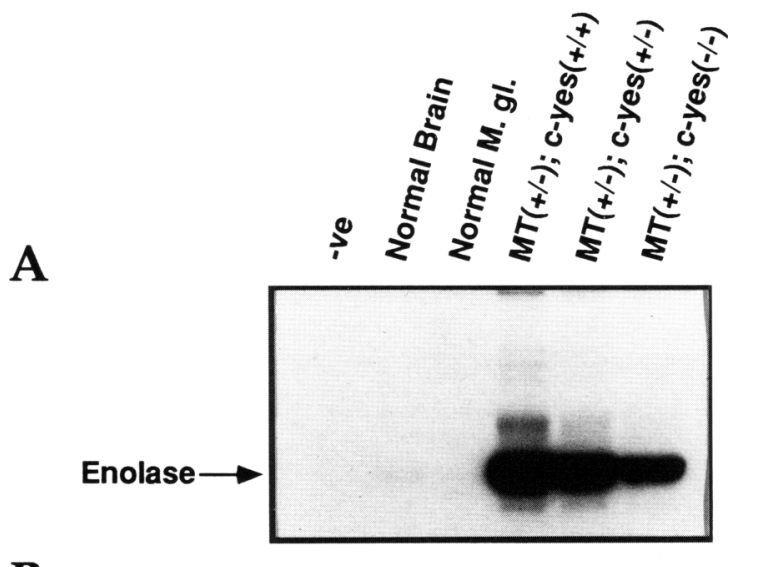

B

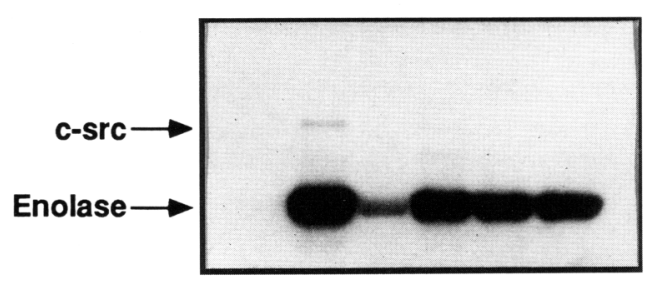

C

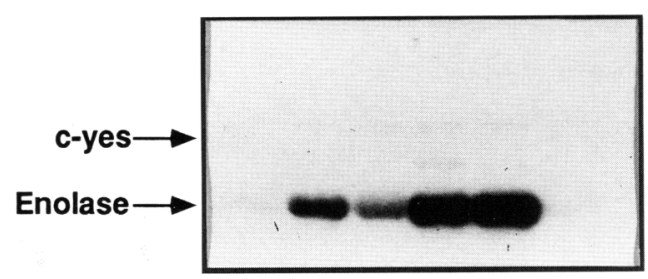

Figure 5. Polyoma middle $\mathrm{T}$ antigen-associated $\mathrm{c}$-Src kinase activity in mammary tumors of mice lacking functional c-Yes. Tissue extracts from mammary tumors of multiparous females $\mathrm{MT} \mid+/-) ; \mathrm{c}-y e s|+1+|(\mathrm{MT} \# 1907$ at 90 days of age), $\mathrm{MT}(+1$ $-1 ; \mathrm{c}-y e s(+1-)(\mathrm{MT} \# 39$ at 138 days of age), MT|+1-);cyes(-/ -) (MT\#119 at 150 days of age) were used for in vitro kinase assays of middle $\mathrm{T}$ antigen $(A), \mathrm{c}-\mathrm{Src}(B)$, and $\mathrm{c}-\mathrm{Yes}(C)$. Protein extracts were incubated with Glu-Glu antibody, which recognizes PyV middle $\mathrm{T}$ antigen, with monoclonal antibody recognizing Src (Ab.1, Oncogene Sci.), or with a monoclonal antibody recognizing Yes $(3 \mathrm{H} 9)$. Protein lysates from brain and nontransgenic mammary gland (normal M.gl.) were used as + ve and - ve controls, respectively. Normal rabbit serum was incubated with lysates from brain tissue to serve as nonspecific control $(-\mathrm{ve})$. The positions of enolase, $\mathrm{c}-\mathrm{Src}$, and $\mathrm{c}$-Yes are indicated by arrows.
c-Src kinase activity between wild-type and c-Yes-deficient strains (Fig. 5B). However, no detectable c-Yes kinase activity could be observed in middle $T$ antigen-induced mammary tumors derived from c-Yes-deficient mice (Fig. 5C). Taken together, these findings argue that activation of the c-Yes kinase is not required for the induction of mammary tumors by the PyV middle T oncogene.

\section{Discussion}

Our observations provide evidence that c-Src activity is required for the rapid production of metastatic mammary tumors in transgenic mice expressing the PyV middle $\mathrm{T}$ oncogene. In contrast to the rapid development of mammary tumors observed in MMTV/PyV middle T antigen mice heterozygous for a disrupted c-src gene (Soriano et al. 1991), mice expressing PyV middle $T$ antigen in the absence of a functional c-Src rarely develop mammary tumors. However, these mice eventually develop benign mammary epithelial hyperplasias that correlate with the activation of the PyV middle $T$ antigen-associated c-Yes kinase. Conversely, mice expressing the middle $\mathrm{T}$ antigen transgene in a c-yes-deficient background develop multifocal mammary tumors with $100 \%$ penetrance. These observations support the hypothesis that activation of a signal transduction pathway involving $c$-Src is responsible for the rapid production of mammary tumors observed in MMTV/PyV middle T antigen transgenic mice.

Because the PyV middle $\mathrm{T}$ oncogene is known to associate and activate c-Src, c-Yes, and Fyn tyrosine kinases (Courtneidge and Smith 1983; Kornbluth et al. 1987; Cheng et al. 1988; Kypta et al. 1988|, the activity of these kinases were initially assessed in mammary tumor extracts derived from different MMTV/PyV middle T antigen strains using in vitro kinase assays. Consistent with observations made with middle $\mathrm{T}$ oncogene-expressing fibroblast cell lines, association of PyV middle $\mathrm{T}$ antigen with c-Src and c-Yes resulted in activation of their intrinsic tyrosine kinase activities. Whereas the Fyn tyrosine kinase is capable of associating with PyV middle $T$ antigen, this protein-protein interaction does not result in a significant increase in its tyrosine kinase activity in fibroblasts (Kypta et al. 1988) or in PyV middle $\mathrm{T}$ antigen-induced mammary tumors (C. Guy, unpubl.). In contrast, the closely related hamster PyV ( $\mathrm{HaPyV}$ ) encodes a middle $\mathrm{T}$ antigen product that is capable of associating and activating the Fyn tyrosine kinase but was unable to complex with c-Src and c-Yes tyrosine kinases (Courtneidge et al. 1991). Interestingly, unlike the mouse PyV, which induces a variety of epithelial tumors including mammary tumors (Berebbi et al. 1990), expression of hamster PyV middle T antigen is associated with the induction of lymphoid tumors (Courtneidge et al. 1991). It is conceivable that the tumor type induced by these viral oncogenes may be dependent on the nature of the Src family member that is activated. Future experiments directed toward expressing the 
HaPyV middle $T$ antigen in the mammary epithelium should allow this question to be addressed.

Direct evidence for the involvement of the c-src protooncogene in mammary tumorigenesis derives from the results of the interbreeding between the MMTV/PyV middle $\mathrm{T}$ transgenic mice and mice encoding a disrupted c-src gene (Soriano et al. 1991). Although we could detect expression of middle $\mathrm{T}$ antigen-encoded RNA and protein from the mammary glands of these c-Src-deficient transgenic mice (Figs. 2 and 4), these mice rarely developed mammary tumors. In contrast, all transgenic mice that were heterozygous for the disrupted c-src allele or that carried both wild-type c-src alleles developed multifocal mammary tumors with similar kinetics. These mice also developed metastasis to the lung with high frequency $(95 \%)$. Although MMTV/PyV middle T antigen mice lacking c-Src function rarely develop mammary tumors, mammary epithelial hyperplasias were often observed in these animals (Fig. 3E,F). It is conceivable that these hyperplasias were the result of activation of c-Yes by PyV middle T antigen because elevated levels of c-Yes kinase activity can be detected in these tissues. However, given the infrequent occurrence of mammary tumors in these mice, the additional activation of c-Src appears to be required for the mammary cell to acquire the full malignant phenotype.

Further evidence implicating the PyV middle $\mathrm{T}$ antigen/c-Src complex in mammary tumorigenesis derives from observations from the interbreeding of MMTV/ middle strains with c-Yes-deficient mice. Unlike $\mathrm{MMTV} /$ middle $\mathrm{T}$ antigen/c-Src-deficient mice, transgenic mice expressing the middle $T$ oncogene in a c-yesdeficient background develop multifocal mammary tumors with $100 \%$ penetrance (Table 1 ). The inability of the PyV middle $\mathrm{T}$ antigen/c-Yes complex to efficiently transform the mammary epithelium in the absence of c-Src does not appear to be the result of an overall lower level of PyV middle $\mathrm{T}$ antigen-associated kinase activity, as the levels of PyV middle $\mathrm{T}$ antigen-associated kinase are comparable between c-Src- and c-Yes-deficient strains (cf. Fig. 4A and 5A). One possible explanation for these observations is that the middle $\mathrm{T} / \mathrm{c}-\mathrm{Src}$ complex may have substrates that are distinct from the middle $\mathrm{T} / \mathrm{c}$-Yes complex and these are required for cellular transformation. In this regard, analyses of mammary gland extracts from c-Src-deficient, c-Yes-deficient, and wild-type mice carrying the transgene with anti-phosphotyrosine-specific antibodies have revealed no obvious differences in the pattern of phosphorylated proteins between these tissues (data not shown). However, these analyses may not be sensitive enough to detect subtle differences in substrate specificity between $\mathrm{c}$-Src and c-Yes.

Another possible explanation for these findings is that $\mathrm{c}-\mathrm{Src}$ and $\mathrm{c}$-Yes are expressed in different cell types in the mammary gland and that tumor precursor cells only express c-Src. However, the immunoprecipitation/immunoblot analyses with PyV middle $\mathrm{T}$ antigen-specific antibodies and either c-Src- or c-Yes-specific antibodies revealed that middle $\mathrm{T}$ antigen is complexed with both
c-Src and c-Yes. Because the expression of middle T antigen is driven by the MMTV long terminal repeat (LTR) and this enhancer is transcriptionally active in identical cell types, it can be argued that c-Src and c-Yes are coexpressed in the mammary tumor cell. Alternatively, it is also possible that inactivation of c-Src indirectly affects tumor formation by affecting secondary factors involved in tumor progression. c-Src-deficient mice develop osteopetrosis and are runted (Soriano et al. 1991). However, the induction of other tumors by PyV middle $\mathrm{T}$ antigen is not affected by disruption of c-src in these mice (Thomas et al. 1993).

Another cell type that is exquisitely sensitive to transformation by middle $\mathrm{T}$ antigen is the endothelial cell (Bautch et al. 1987; Williams et al. 1988). In contrast to the mammary epithelial cells, transformation of the endothelial cells or established fibroblasts by PyV middle T antigen does not require functional c-Src (Thomas et al. 1993). However, endothelial expression of middle T antigen in a c-yes-deficient background resulted in reduction of the number of endothelial tumors that arose after a longer latency period (P. Soriano, pers. comm.). Conversely, in certain PyV-transformed rat cell lines, inducible expression of antisense $\mathrm{c}$-src construct results in the reduction of the tumorigenic properties of these lines (Amini et al. 1986). Hence, activation of closely related Src family tyrosine kinases may have dramatically different outcomes in different cell types.

Consistent with these observations, there are several reports demonstrating elevated levels of c-Src tyrosine kinase activity in a large proportion of primary human breast cancers (Jacobs and Rubsamen 1983; Rosen et al. 1986; Ottenhoff-Kalff et al. 1992). Because equivalent levels of c-Src protein were detected in matched normal and tumor tissues, the elevated c-Src tyrosine kinase activity observed is likely attributable to qualitative rather than quantitative changes in the regulation of c-Src activity (Rosen et al. 1986). We have recently detected elevated c-Src and c-Yes kinase activity in mammary tumors derived from mice carrying an MMTV/unactivated neu transgene (Guy et al. 1992b; Muthuswamy et al. 1994). It is conceivable that like the PyV middle T oncogene, Neu-induced mammary tumorigenesis may also require the function of these Src family members. Ligand dependent activation of other receptor tyrosine kinases, like the platelet-derived growth factor (PDGF) receptor (Kypta et al. 1990) or the colony-stimulating factor-1 receptor (CSF-1R) (Courtneidge et al. 1993), results in the activation of c-Src, c-Yes, and Fyn tyrosine kinase activities. Microinjection of dominant-negative mutants of c-Src into cells can effectively ablate PDGF-mediated mitogenesis (Twamley-Stein et al. 1993). Future crosses between MMTV/unactivated Neu mice and c-Src-deficient strains should allow us to determine whether or not c-Src is required for Neu-mediated mammary tumorigenesis.

Although these experiments have focused on the role of c-Src in PyV middle T antigen-induced tumorigenesis, this study may have general implications in the understanding of how oncogene products participate individ- 
ually in a signal transduction pathway in vivo. For example, it should be possible to assess the relative contribution of other components of a tyrosine kinase signal transduction pathway to the tumor phenotype by interbreeding these mice to other strains deficient in genes thought to be involved in signaling cellular proliferation. Application of this genetic approach to other mitogenic signal transduction pathways may provide important insights into the collaboration of oncogene products in mammary tumorigenesis.

\section{Materials and methods}

\section{Identification of transgenic mice}

The PyV middle T antigen transgenic line, MT\#634, was generated as described previously (Guy et al. 1992a). Briefly, a c-DNA encoding PyV middle $T$ antigen (Treisman et al. 1981) was inserted into an MMTV LTR expression vector. The MMTV component was derived from plasmid PA9 (Huang et al. 1981), whereas the SV40 transcriptional processing signals at the $3^{\prime}$ end of the cDNA were obtained from plasmid CDM8 (Seed and Aruffo 1987). Fertilized one-cell mouse embryos were recovered and microinjected with the pMMTV MT construct. Homozygous $s \mathrm{sc}(-1-)$ and yes $(-1-)$ mutant mice were generated by homologous recombination in embryonic stem cells and kindly provided by Philippe Soriano (Soriano et al. 1991; P. Soriano, unpubl.). The genotypes of the progeny derived from the cross of the MT\#634 strain and the $s r c \mid-1-$ ) and yes $(-1-1$ mice were confirmed by isolation of genomic DNA from a 1.5$\mathrm{cm}$ tail clipping as described by Muller et al. (1988). The nucleic acid pellet was resuspended in $100 \mu$ l of distilled water at an approximate concentration of $1 \mu \mathrm{g} / \mu \mathrm{l}$, and $15 \mu \mathrm{l}$ of the DNA solution was digested either with 30 units of $B a m H I$ or 30 units of EcoRI. After gel electrophoresis and Southern blot transfer (Southern 1975), the Gene-Screen membranes (DuPont) bearing the BamHI-cleaved DNA were hybridized with a PyV middle T antigen cDNA probe radiolabeled with $\left[\alpha^{-32} \mathrm{P}\right] \mathrm{dCTP}$ by random priming (Feinberg and Vogelstein 1984). The Gene-Screen filters bearing the EcoRI-cleaved genomic DNA were treated in an identical fashion with the exception that they were hybridized to a radiolabeled probe, a 350-bp SalI-BamHI fragment from the $5^{\prime}$ end of p12 (Soriano et al. 1991). The c-yes genotypes were determined by hybridizing EcoRI-cleaved genomic DNA with a probe from the $3^{\prime}$ side of c-yes (P. Soriano, unpubl.).

\section{Expression data}

Whole-cell RNA was isolated from tissues by guanidine thiocyanate extraction and $\mathrm{CsCl}$ gradient fractionation (Chirgwin et al. 1979). RNA yield was determined after resuspension in sterile water by UV adsorption at $260 \mathrm{~nm}$. RNA probes were made with either Bluescript (Stratagene) or pGEM vectors (Promega), and RNase protection assays were performed as described by Melton et al. (1984), using $10 \mu \mathrm{g}$ of total RNA. The PyV middle $\mathrm{T}$ antigen riboprotection probe, pSP $65 \mathrm{mT}$, was obtained from $\mathrm{J}$. Hassell (McMaster University) and contains a 203-bp HindIIIAccI fragment of the PyV early region (PyV nucleotides 165368 ) inserted into the HindIII-AccI sites of pSP65 (Promega). To ensure that equal amounts of RNA were analyzed, an internal control, plasmid rpL 32 27.3.7, obtained from M. Shen (Harvard Medical School, Boston, MA), was added to the hybridization reaction. It encodes an Xholl-DraI fragment of the mouse ribosomal gene rpL32 inserted into the corresponding sites of the plasmid Bluescript KS (Stratagene). All plasmids were isolated as described previously (Sinn et al. 1987).

\section{Immunoprecipitation and in vitro kinase analyses}

Tissue samples were frozen in liquid nitrogen and ground to a fine powder by using cooled pestle and mortar. Cells were lysed rapidly on ice for $30 \mathrm{~min}$ in buffer TNE [ $50 \mathrm{~mm}$ Tris (pH 8.0), 150 $\mathrm{mM} \mathrm{NaCl}, 1 \% \mathrm{NP}-40,2.5 \mathrm{~mm}$ EDTA, $1 \mathrm{~mm}$ sodium orthovanadate, $10 \mathrm{~mm} \mathrm{NaF}, 1 \%$ aprotinin, $10 \mathrm{~mm}$ leupeptin, $50 \mu \mathrm{g} / \mathrm{ml}$ TLCK, and $100 \mu \mathrm{g} / \mathrm{ml}$ TPCK]. The protein concentrations of the whole-tissue extracts were measured using the Bio-Rad protein assay kit (Bio-Rad). Equal amounts of protein $(500 \mu \mathrm{g})$ from tissue extracts were used for the immunoprecipitations. Tissue extracts were incubated with an excess of antibodies specific to c-Src (mAb 327, Oncogene Sci.), c-Yes (Sukewaga et al. 1990), Fyn (Kypta et al. 1990) and PyV middle T antigen (Glu-Glu; Grussenmeyer et al. 1985) and incubated with $30 \mu$ l of protein$\mathrm{G} /$ Sepharose fast flow (Pharmacia) for $1 \mathrm{hr}$. Immunoprecipitates were washed five times with TNE buffer and once with $2 \times$ kinase buffer containing $200 \mathrm{~mm}$ HEPES at $\mathrm{pH} 7.0$ and $10 \mathrm{~mm}$ $\mathrm{MnCl} 2$. The beads were resuspended in $9 \mu \mathrm{l}$ of $2 \times$ kinase buffer and a mixture containing $10 \mu \mathrm{Ci}$ of $\left[\gamma^{-32} \mathrm{P}\right]$ ATP $(4000 \mathrm{mCi} / \mathrm{ml}$; Amersham Corp.l, and $10 \mu \mathrm{g}$ of acid denatured enolase was added. The reaction mixtures was incubated at room temperature for $5 \mathrm{~min}$ and stopped with sample buffer $(10 \mathrm{mM}$ Tris at $\mathrm{pH}$ $6.8,2 \%$ SDS, $10 \%$ glycerol, $5 \% \beta$-mercaptoethanol). The reaction mixture was electrophoresed on a $9-10 \%$ SDS-polyacrylamide gel. The gel was fixed in $30 \% \mathrm{MeOH} / 7 \% \mathrm{AcOH}$ and incubated in $1 \mathrm{~N} \mathrm{KOH}$ at $55^{\circ} \mathrm{C}$ for 30 min with gentle shaking. The base was neutralized with an equal volume of $1 \mathrm{~N} \mathrm{HCl}$, and the gel was rinsed in $30 \% \mathrm{MeOH}$ before drying. The radiolabeled bands were visualized following autoradiography on X-ray film (Kodak).

\section{Immunoblot analysis}

To detect the association of c-Src and c-Yes proteins with PyV middle $\mathrm{T}$ antigen in mammary tumors, $500 \mu \mathrm{g}$ of total cellular protein was immunoprecipitated (as described above) with a polyclonal rat antiserum directed against the middle $T$ antigen. Immunoprecipitates were loaded on a 9\% SDS-polyacrylamide gel and transferred electrophoretically onto Immobilon-PVDF membranes (Millipore). The membranes were blocked for $3 \mathrm{hr}$ in PBS containing 5\% skim milk and probed with a 1:000 dilution of $\mathrm{mAb} 327$ or antipeptide polysera pyes 6 . The filters were agitated at room temperature for $2 \mathrm{hr}$ and washed four times with PBS containing $0.05 \%$ Tween 20 . The blots were reacted with specific antibody-horseradish peroxidase (HRP) conjugate (1:5000 dilution) (Promega) for $30 \mathrm{~min}$ and washed, and the proteins were visualized with the enhanced chemiluminescence (ECL) detection system (Amersham).

\section{Histological evaluation}

Complete autopsies were performed as described by Muller et al. (1988). Tissues were fixed in $4 \%$ paraformaldehyde, blocked in paraffin, sectioned at $5 \mu \mathrm{m}$, stained with hematoxylin and eosin, and examined as indicated in the legend to Figure 2. Whole mounts of mammary fat pads were prepared as described by Vonderhaar and Greco (1979).

\section{Acknowledgments}

We thank Michael Shen, Tadashi Yamamoto, and Sara Courtneidge for providing the various nucleic acid and antibody 
probes used in this study. We appreciate the excellent photographic support of Robert Munn and the technical assistance of Monica Graham. We also thank Michael Rudnicki and John Hassell for their comments, and Laurie Kendry and Barb Holdcroft for preparation of the manuscript. This work was supported by research grants awarded by the National Cancer Institute of Canada and the Medical Research Council of Canada. This work was also partially supported by grant RO1-CA S4285 from the National Cancer Institute (U.S.) and by a grant awarded to P.S. by National Institute of Child Health and Human Development (NICHD). W.J.M is a recipient of a National Cancer Institute Scientist award, C.T.G. was supported by a studentship provided by the Cancer Research Society, and S.K.M. is a Canadian International Development Agency (CIDA) scholar.

The publication costs of this article were defrayed in part by payment of page charges. This article must therefore be hereby marked "advertisement" in accordance with 18 USC section 1734 solely to indicate this fact.

\section{References}

Aguzzi, A., E.F. Wagner, R.L. Williams, and S.A. Courtneidge. 1990. Sympathetic hyperplasia and neuroblastomas in transgenic mice expressing polyoma middle T antigen. New Biol. 6: $533-543$.

Amini, S., V. DeSeau, S. Reddy, D. Shalloway, and J.B. Bolen. 1986. Regulation of pp60 c-src synthesis by inducible RNA complementary to c-src mRNA in polyomavirus-transformed rat cells. Mol. Cell. Biol. 7: 2305-2316.

Bautch, V.L., J. Toda, J.A. Hassell, and D. Hanahan. 1987. Endothelial cell tumors develop in transgenic mice carrying the polyomavirus middle T oncogene. Cell 51: 529.

Berebbi, M., P.M. Martin, Y. Berthois, A.M. Bernard, and D. Blangy. 1990. Estradiol dependence of the specific mammary tissue targeting of polyoma virus oncogenicity in nude mice. Oncogene 5: 505-509.

Cheng, S.H., H. Piwnica-Worms, R.W. Harvey, T.M. Roberts, and A.E. Smith. 1988. The carboxy terminus of $p p 60^{c-s r c}$ is a regulatory domain and is involved in complex formation with the middle-T antigen of polyomavirus. Mol. Cell. Biol. 8: 1736-1747.

Chirgwin, J.M., A.E. Przybyla, R.J. MacDonald, and W.J. Rutter. 1979. Isolation of biologically active ribonucleic acid from sources enriched in ribonuclease. Biochemistry 18: 5294 5299.

Courtneidge, S.A. and A. Hebner. 1987. An $81 \mathrm{kDa}$ protein complexed with middle $T$ antigen nd pp60 c-src: A possible phosphatidylinositol kinase. Cell 50: 1031-1037.

Courtneidge, S.A. and A.E. Smith. 1983. Polyoma virus transforming protein associates with the product of the c-src gene. Nature 303: 435-439.

Courtneidge, S.A., L. Goutebroze, A. Cartwright, A. Heber, S. Scherneck, and J. Feunteun. 1991. Identification and characterization of the hamster polyomavirus middle $\mathrm{T}$ antigen. $J$. Virol. 6: 3301-3308.

Courtneidge, S.A., R. Dhand, D. Pilat, G.M. Twamely, M.D. Waterfield, and M. Roussel. 1993. Activation of src family kinases by colony stimulating factor- 1 and their association with its receptor. EMBO J. 12: 934-950.

Escot, C., C. Theillet, R. Lidereau, F. Spyvatos, M.H. Champeme, J. Gest, and R. Callahan. 1986. Genetic alteration of the c-myc proto-oncogene (MYC) in human primary breast carcinomas. Proc. Natl. Acad. Sci. 83: 4834-4838.
Feinberg, A.P. and B. Vogelstein. 1983. A technique for radiolabeling DNA restriction endonuclease fragments to high specific activity. Anal. Biochem. 132: 6-13.

Grussenmeyer, T., K.Z. Scheidtmann, M.A. Hutchinson, W. Eckhart, and G. Walter. 1985. Complexes of polyoma virus medium $\mathrm{T}$ antigen and cellular proteins. Proc. Natl. Acad. Sci. 82: 7952-7954.

Guy, C.T., R.D. Cardiff, and W.J. Muller. 1992a. Induction of mammary tumors by expression of polyomavirus middle $T$ oncogene: A transgenic mouse model for metastatic disease. Mol. Cell. Biol. 12: 954-961.

Guy, C.T., M.A. Webster, M. Schaller, T.J. Parson, R.D. Cardiff, and W.J. Muller. 1992b. Expression of the neu proto-oncogene in the mammary epithelium of transgenic mice induces metastatic disease. Proc. Natl. Acad. Sci. 89: 10578-10582.

Huang, A.L., M.C. Ogtrowski, D. Berard, and G.L. Hager. 1981. Glucocorticoid regulation of Ha-MuSV p21 conferred by sequences from mouse mammary tumor virus. Cell 27: 245255.

Jacobs, C. and H. Rubsamen. 1983. Expression of pp60 ${ }^{\text {c-src }}$ protein kinase in adult and fetal human tissues. High activities in some sarcomas and mammary carcinomas. Cancer Res. 43: 1696-1702.

King, C.R., M.H. Kraus, and S.A. Aaronson. 1985. Amplification of a novel v-erbB-related gene in a human mammary carcinoma. Science 229: 974-976.

Kornbluth, S., M. Sudol, and H. Hanafusa. 1987. Association of the polyomavirus middle $\mathrm{T}$ antigen with c-yes protein. $\mathrm{Na}$ ture 325: 171-173.

Kypta, R.M., A. Hemming, and S.A. Courtneidge. 1988. Identification and characterization of p59 fyn (a src-like protein tyrosine kinase) in normal and polyoma virus transformed cells. EMBO I. 7: 3837-3844.

Kypta, R.M., Y. Goldberg, E.T. Ulug, and S.A. Courtneidge. 1990. Association between the PDGF receptor and members of the src family of tyrosine kinases. Cell 62: 481-492.

Melton, D., A.P.A. Krieg, M.R. Rebagliati, T. Maniatis, K. Zinn, and M.R. Green. 1984. Efficient in vitro synthesis of biologically active RNA and RNA hybridization probes from plasmids containing a bacteriophage SP6 promoter. Nucleic Acids Res. 12: 7035-7056.

Muller, W.J., E. Sinn, P.K. Pattengale, R. Wallace, and P. Leder. 1988. Single-step induction of mammary adenocarcinoma in transgenic mice bearing the activated c-neu oncogene. Cell 54: 105-115.

Muthuswamy, S.K., P.M. Siegel, D.L. Dankort, M.A. Webster, and W.J. Muller. 1994. Mammary tumors expressing the neu proto-oncogene possess elevated c-src tyrosine kinase activity. Mol. Cell. Biol. 14: (in press).

Ottenhoff-Kalff, A.E., G. Rijksen, E.A.C.M. van Beurden, A. Hennipman, A.A. Michels, and G.E.J. Staal. 1992. Characterization of protein tyrosine kinases from human breast cancer: Involvement of the c-src oncogene product. Cancer Res. 52: 4773-4778.

Pallas, D.C., L.K. Shahrik, B.L. Martin, S. Jasper, T.B. Miller, D.L. Brautigan, and T.M. Roberts. 1990. Polyoma small and middle $T$ antigens and SV40 small $t$ antigen form stable complexes with protein phosphatase 2A. Cell 60: 167-176.

Peles, E., S. Bacus, R. Koksi, H.S. Lu, D. Weu, S. Ogolen, R. Ben Levy and Y. Yarden. 1992. Isolation of the Neu/her 2 stimulatory ligand: A $44 \mathrm{kDa}$ glycoprotein that induces differentiation of mammary tumor cells. Cell 69: 205-216.

Rosen, N., J.B. Bolen, A.M. Schwartz, P. Cohen, V. DeSeau, and M.A. Israel. 1986. Analysis of pp60 $0^{\mathrm{c}-\mathrm{src}}$ protein kinase activity in human tumor cell lines and tissues. $J$. Biol. Chem. 261: 13754-13759. 
Guy et al.

Seed, B. and A. Aruffo. 1987. Molecular cloning of the CD2 antigen, the $\mathrm{T}$ cell erythrocyte receptor, by rapidimmunoselection procedure. Proc. Natl. Acad. Sci. 84: 3365-3369.

Sinn, E., W.J. Muller, P. Pattengale, I. Tepler, R. Wallace, and P. Leder. 1987. Coexpression of MMTV/v-Ha-ras and MMTV/ c-myc genes in transgenic mice: Synergistic action of oncogenes in vivo. Cell 49: 465-475.

Slamon, D.J., G.M. Clark, S.G. Wong, W.J. Levin, A. Ullrich, and W.L. McGuire. 1987. Human breast cancer: Correlation of relapse and survival with amplification of the HER-2/neu oncogene. Science 235: 177-182.

Slamon, D.J., W. Godolphin, L.A. Jones, J.A. Holt, S.C. Wong, D.E. Keith, W.J. Levin, S.G. Stuart, J. Udore, A. Ullrich, and M.F. Press. 1989. Studies of the HER-2/neu protooncogene in human breast and ovarian cancer. Science 244: 707-712.

Soriano, P., C. Montgomery, R. Geske, and A. Bradley. 1991. Targeted disruption of the c-src proto-oncogene leads to osteopetrosis in mice. Cell 64: 693-702.

Southern, E.M. 1975. Detection of specific sequences among DNA fragments separated by gel electrophoresis. I. Mol. Biol. 98: 503-517.

Sukegawa, J., T. Akatsuka, I. Sugawara, S. Mori, T. Yamamoto, and K. Toyoshima. 1990. Monoclonal antibodies to the amino-terminal sequence of the c-yes gene product as specific probes of its expression. Oncogene 5: 611-614.

Talmage, D.A., R. Freund, A.T. Young, J. Dahl, C.J. Dawe, and T.L. Benjamin. 1989. Phosphorylation of middle $T$ antigen by pp60 $6{ }^{\text {-src: }}$ A switch for binding of phosphatidylinositol 3-kinase and optimal tumorigenesis. Cell 59: 55-65.

Thomas, J.E, A. Aguzzi, P. Soriano, E.F. Wagner, and J. Brugge. 1993. Induction of tumor formation and cell transformation by polyoma middle $\mathrm{T}$ antigen in the absence of src. Oncogene 8: 2521-2526

Treisman, R., U. Novak, J. Favaloro, and R. Kamen. 1981. Transformation of rat cells by an altered polyoma virus genome expressing only the middle $\mathrm{T}$ antigen protein. Nature 292: 595-600.

Twamley-Stein, G.M., Pepperkok, R., Ansorge, W., and Courtneidge, S.A.E. 1993. The Src family tyrosine kinases are required for platelet-derived growth factor mediated signal transduction in NIH 3T3 cells. Proc. Natl. Acad. Sci. 90: 7696.

Vonderhaar, B.K. and A.E. Greco. 1979. Lobulo-alveolar development of mouse mammary glands is regulated by thyroid hormones. Endocrinology 2: 409-418.

Walter, G., R. Ruediger, C. Slaughter, and M. Mumby. 1990. Association of protein phosphatase $2 \mathrm{~A}$ with polyoma virus medium tumor antigen. Proc. Natl. Acad. Sci. 87: 25212525.

Wen, D., E. Peles, R. Cupples, S.V. Suggs, S.S. Bacus, Y. Luo, G. Trail, S. Hu, S. Silbiger, R. Ben-Levy, R.A. Koski, H.S. Lu, and Y. Yarden. 1992. Neu differentiation factor: A transmembrane glycoprotein containing an EGF domain and an immunoglobulin homology unit. Cell 69: 559-572.

Whitman, M., D.R. Kaplan, B. Schaffhausen, L. Cantley, and T.M. Roberts. 1985. Association of phosphatidylinositol kinase activity with polyoma middle $\mathrm{T}$ antigen competent for transformation. Nature 315: 239-242.

Williams, R.L., S.A. Courtneidge, and E.F. Wagner. 1988. Embryonic lethalities and endothelial tumors in chimeric cell mice expressing polyomavinus middle $\mathrm{T}$ oncogene. Cell 52: 121-131.

Yokota, J., T. Yamamoto, K. Toyoshima, M. Terada, T. Sugimura, H. Battifora, and M.J. Cline. 1986. Amplification of c-erbB-2 oncogene in human adenocarcinomas in vivo. Lancet I: 765-767. 


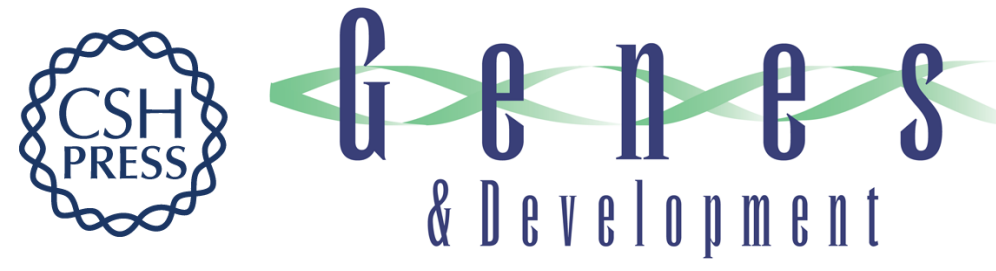

\section{Activation of the c-Src tyrosine kinase is required for the induction of mammary tumors in transgenic mice.}

C T Guy, S K Muthuswamy, R D Cardiff, et al.

Genes Dev. 1994, 8:

Access the most recent version at doi:10.1101/gad.8.1.23

References This article cites 43 articles, 14 of which can be accessed free at:

http://genesdev.cshlp.org/content/8/1/23.full.html\#ref-list-1

License

Email Alerting

Service

Receive free email alerts when new articles cite this article - sign up in the box at the top right corner of the article or click here.

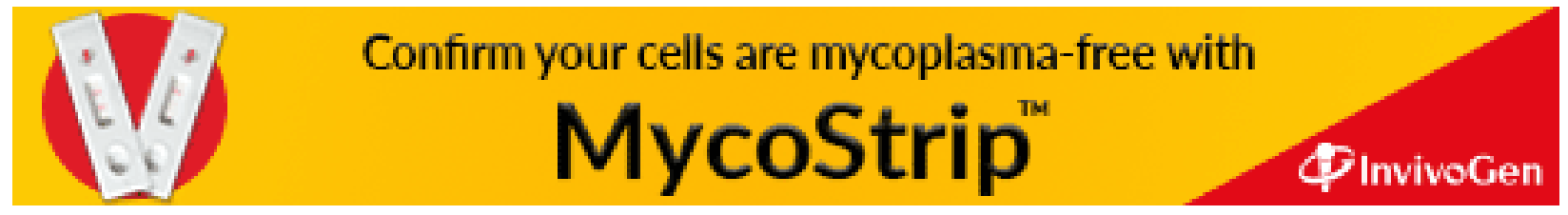

